DOI 10.18551/rjoas.2021-11.14

\title{
CAPITALIZATION RATE, INTERNALLY GENERATED INTANGIBLE ASSETS, AND THE VALUE RELEVANCE OF ACCOUNTING INFORMATION: EVIDENCE FROM INDONESIA
}

\author{
Widyatama Wayan Wina*, Wirama Dewa Gede \\ Faculty of Economics and Business, University of Udayana, Bali, Indonesia \\ *E-mail: wina widyatama@yahoo.com
}

\begin{abstract}
The purpose of this study is to examine the effect of internally generated intangible assets' capitalization rate at the firm level on the value relevance of accounting information. Capitalization rate is defined as the tendency of a firm to capitalize their expenditures that may have future benefit for the firm. In accordance with the matching concept, expenditures that may have future benefit for the firm should be capitalized to provide more accurate information to investors related to the financial performance of the firm. Thus, it is hypothesized in this study that a greater capitalization rate for the internally generated intangible asset improves the value relevance of accounting information. Timeliness of publication and negative earnings presence were included as the controlling variables. 31 firms were selected through the purposive sampling method. The data collected are secondary data and the data analysis technique utilized was the multilple linear regression analysis. However, the analysis results showed that capitalization rate does not have a significant effect on the value relevance of accounting information with timeliness and negative earnings presence as the controlling variables. After the inclusion of firms that do not use Indonesian Rupiah as their reporting currency, the total sample only increased by 2 , with a total of 33 firms. Despite this inclusion, the hypothesis was still rejected. The data also shows that most firms provide inadequate information regarding their intangible assets.
\end{abstract}

\section{KEY WORDS}

Capitalization rate, internally generated intangible assets, value relevance, timeliness, negative earnings presence, firm size.

Quoted from the Statement of Financial Accounting Concepts no. 8 (SFAC 8), general purpose financial reporting has the objective of providing financial information which is useful for equity investors, creditors, and other users in decision making (IASB, 2010). However, based on a preliminary study, by comparing the periods before the convergence of the PSAK (Indonesia's Statements of Financial Accounting Standards) with the IFRS (International Financial Reporting Standards) and after the convergence, that is comparing between 2006 - 2010 and 2011 - 2016, the value relevance of accounting information in Indonesia has experienced a decline. This is similar to the research findings of Bokpin (2013) which revealed that in Ghana Stock Exchange (GSE), despite the significant adoption of the IFRS, the improvement in disclosure and value relevance were not significant. The preliminary study was continued by comparing the decline in value relevance of accounting earnings and book value between firms in the manufacturing industry and the service industry in Indonesia. It was found that the decline in value relevance was greater for the service industry. One of the possible explanations is that the service industry, which tends to have more expenditure or investments on human resource training and research and developments, have a greater tendency to directly expense a larger proportion of these expenditure compared to the manufacturing and raw resources industry, in which the expenditures and investments tend to be more focused on tangible assets or readily capitalizable expenditures. Based on this categorization, one of the factors which may have led to this difference in value relevance is the capitalization rate of firms. Similarly, Badu and Kingsley (2018) and Beisland and Hamberg (2013) also suggested this in their research hypothesis. 
In Badu and Kingsley's (2018) research, they first hypothesized that the book value of the service industry is more value relevant to the stock price than earnings, while for the industrial sector (produce goods) earnings is more relevant to stock price. However, their research results revealed that their hypotheses were rejected. This could be because each firm has their own specific tendency which cannot be generalized based on their industry group. Beisland and Hamberg (2013) divided industries into two categories based on their tendency of having important resources capitalized as assets, namely the: 1) traditional company, in which are firms that undertake more investments in resources that can be capitalized, and 2) non-traditional company, in which are firms that undertake more investments in research and human capital. They further explained that the direct expensing of investments reduces the ability of balance sheets to measure the intrinsic asset values of firms and introduces unsustainable elements in reported earnings. Growth in unrecognized investments reduces current earnings and creates "hidden reserves" (Penman and Zhang, 2002), while a reduction in the level of investment releases these reserves and increases contemporary earnings. This study argues that the capitalization of research and development expenditures is more conservative than the direct expensing of research expenditures, as the former is more consistent with the matching concept and also minimizes the possibility of opportunistic earnings management.

Each firm would capitalize a different proportion of their investment expenditures, including their research and development $(R \& D)$ expenditures. Thus, generalizing the firm's tendency to capitalize expenditures based on the industry group or modern-traditional category may not be an accurate measure to this tendency. In this study, this tendency is called the capitalization rate. In the financial statement, intangible assets include purchased licenses, renewal cost of legal rights (such as land and concession rights), and internally generated intangible assets from development costs. The proportion of development expenditures capitalized as internally generated intangible assets is determined based on management's discretion. Therefore, this study focuses on the capitalization rate for the internally generated intangible assets. In order to determine whether capitalization rate affects investors' appreciation towards the accounting information produced, the capitalization rate must be assessed at the firm level. Thus, this study attempts to provide empirical evidence regarding the effect of capitalization rate for the internally generated intangible assets on the value relevance of accounting information in Indonesia.

Value relevance of accounting information in this research is defined as the degree of usefulness of accounting information to investors, measured by assessing the explanatory power of the accounting earnings and book value on the stock price of firms. With a greater level of capitalization rate, the accounting information is more consistent with the matching concept. Subsequently, firms with greater capitalization rate are less able to conduct opportunistic earnings management. The accounting information produced would also more accurately depict the actual financial performance of the firm, which allows investors to have a better appreciation towards this information. However, this possibility must still be examined because each firm has a different capitalization rate which cannot be generalized based on their industry type. This study attempts to examine whether the capitalization rate of the listed firms in Indonesia influences the usefulness of their published financial information to the investment decisions of investors, hence the value relevance of accounting information. In addition, several factors related to investment decisions are also examined as the controlling variables in this study to provide better insights to regulators and others interested in the topic regarding how capitalization rate affects the value relevance of accounting information in Indonesia.

In an article published by Valens Research (2016), it was argued that the direct expensing of research and development expenditures leads to extensive volatility in profit and return calculations, which hinders the financial statement users from attaining an accurate depiction of corporate profitability and valuation. This is because the direct expensing of research and development expenditures is not consistent with the matching concept, as the research and development investments may still provide benefit to the firm's revenue in the next few accounting periods. Firms have research and development 
expenditures precisely to provide potential future benefit for the firm. Many may argue that when the research and development investment of a firm fails, it must be directly expensed, but by doing so, the financial statement would not depict the impact of this research and development on the revenue of the firm. The article published by Valens Research (2016) also argued that capitalizing research and development expenditure is actually more conservative than directly expensing it as this would grow the balance sheet, leading to the decrease in adjusted return on assets. This allows investors to better assess the performance of the related research and development expenditure over its estimated economical period. Furthermore, even when certain research and development activities fail to provide significant direct revenue streams for the firm, the firms would still use the results of these investments on other projects they have, which means that it still provides potential benefit for the firm. If firms do not capitalize their research and development expenditures, including the ones that fail to provide direct revenue stream potentials, the information contained in the financial statements can be said to be very likely to give too much credit to successful research and development investments. Thus, if it is not capitalized and periodically expensed, the information provided in the financial statements may lead to an inaccurate assessment of the firm's profitability and valuation, due to its inconsistency with the matching concept.

The capitalization rate is unique for each firm, and therefore it cannot be generalized based on their industry group or other categorizations. To the best of our knowledge, the capitalization rate of firms has never been assessed at the firm level before. Intangible assets in firms' financial statement include purchased licenses, renewal cost of legal rights of land and internally generated intangible assets from development costs for newly developed products. The amount of $R \& D$ expenditures capitalized as internally generated intangible assets are also determined based on management's discretion. Thus, the capitalization rate assessed in this study is the capitalization rate for the internally generated intangible assets.

The presence of negative earnings is included as one of the controlling variables in the study. Badu and Kingsley (2018) suggested in their research results that the financial information are less relevant to investors when firms report negative earnings, while for firms that report positive earnings, the financial information is more relevant to investors in making investment decisions. This implies that under the presence of negative earnings, investors shift their attention or focus away from earnings and book value information and search for other information which could help them make decisions. This was pointed out in Hayn's (1995) research result which revealed that the relationship between earnings and stock price of firm which made profit (positive earnings) and firms that incurred a loss (negative earnings) may not be homogenous. Thus, the presence of negative earnings would very likely lead to a difference in the level of usefulness of financial statement information or the value relevance of accounting information. In order to more accurately examine the effect of capitalization rate on value relevance of accounting information, the presence of negative earnings is therefore applied as one of the control variables in this study.

The second controlling variable considered is the timeliness of publication. Timely, in the SFAC, is identified as one of the qualitative characteristics of useful financial information. To provide relevant information to investors which are capable of influencing their decisions, the information must be made available to them in a timely manner. This also implies that the usefulness of accounting information is impaired or reduced the later these information are made available to investors. Vuran and Adiloğlu (2013) also agreed to this by emphasizing that the usefulness of accounting information depends on its accuracy and timeliness. Erliza et al. (2019) and Vuran and Adiloğlu (2013) revealed that the timeliness of financial information publication is related to several accounting numbers, financial ratios, and auditor reputation. Sjarief et al. (2015) also explained that the lateness of financial reporting is related to the firm's disclosure of internal control. These research findings indicate that if the accounting information are made available to investors late, investors may view this as a form of negative signal, in which investors may either have their own suspicions, become more skeptical to the information, or listen to other form of noises, making the explanatory power of the published accounting information become less pronounced. In order to examine 
the effect of capitalization rate on value relevance, this factor must then be controlled to avoid confusing the influence of timeliness and capitalization rate.

The direct expensing of investments reduces the ability of the balance sheets to measure the intrinsic asset values of firms and introduces unsustainable elements in reported earnings (Beisland and Hamberg, 2013). Internally generated intangible assets can represent the capitalized $R \& D$ expenditure of firms, and is therefore used in this study to calculate the capitalization rate of the firm. If this cost is directly expensed in the period it is incurred, the financial information published would not be able to show or reflect the performance of that investment. At the same time, the direct expensing of R\&D expenditures may be utilized by management to conduct opportunistic earnings management. If the income in one period is high, management might want to fully expense their R\&D expenditures in order to create hidden reserves to mislead investors in subsequent periods. If the expenditures are capitalized, the information displayed in the financial statement will show that the firm is less able to conduct opportunistic earnings management as the expenditures will be amortized in the subsequent years. Based on this line of justification, while simultaneously applying timeliness, firm size, and negative earnings as the controlling variables, the hypothesis proposed is as follows:

$H_{1}$ : Firms with a greater capitalization rate for the internally generated intangible assets have a higher level of value relevance of accounting information than firms with lower capitalization rate.

\section{METHODS OF RESEARCH}

The population of the research is all the companies listed in the IDX or Indonesian Stock Exchange in 2019. Quarterly data of the financial statements published over the years of 2015 - 2019 were used to examine the relationsip between capitalization rate and the value relevance of accounting information. The purposive sampling method was used to determine the research sample, and the sample criteria are as follows: (1) The firm has issued its Initial Public Offering (IPO) before 2015 and is still listed during 2015 - 2019; (2) Firms selected are non-financial industry firms, as this industry has specific regulations that are different from other industries. Inclusion of the financial industry may result in bias results, hence the need to control for industrial effect; (3) The information needed must be completely available or published by the listed firms over the periods of $2015-2019$; (4) The firm must state in the notes to the financial statement that they conduct research and development activities or there are R\&D expenses recognized in the firm's income statement, and there is sufficient information provided to calculate the internally developed intangible assets; (5) Use IDR (Indonesian Rupiah) as the reporting currency in order to increase uniformity of the data analyzed by the researcher. From the population, a total of 31 firms fulfill the requirements as a research sample.

As distinguished by Holthausen and Watts (2001), the combined model (regression model of price on earnings and book value) is used to measure the magnitude of value relevance of accounting information, by determining the coefficient of determination $\left(R^{2}\right)$ of the regression. This method is also used in prior studies, (Collins et al., 1997; Lev et al., 1999; Kousenidis, 2009; Balachandran and Mohanram, 2010; Wendt, 2010; Zacharias, 2015; and Badu and Kingsley, 2018).

$$
\frac{\mathrm{P}_{\mathrm{I}, \mathrm{t}}}{\mathrm{P}_{\mathrm{I}, \mathrm{t}-1}}=\alpha_{0}+\alpha_{1} \frac{\mathrm{EPS}_{\mathrm{I}, \mathrm{t}}}{\mathrm{P}_{\mathrm{I}, \mathrm{t}-1}}+\alpha_{2} \frac{\mathrm{BVPS}_{\mathrm{I}, \mathrm{t}}}{\mathrm{P}_{\mathrm{I}, \mathrm{t}-1}}+\varepsilon_{\mathrm{I}, \mathrm{t}}
$$

To calculate the capitalization rate for the internally developed intangible assets, the following formula was developed:

$$
\frac{\left(\mathrm{IA}_{t}-\mathrm{IA}_{t-1}+\mathrm{Amort}_{t}-\mathrm{ACQ} \cdot \mathrm{IA}_{t}\right)}{\mathrm{TCI}+\mathrm{AI}}
$$


Where:

$I A_{t}=$ Intangible assets reported for the year ended $t ;$

Amort $_{t}=$ Amortization expense of IA during the accounting period $t$;

$A C Q . I A_{t}=$ Addition in Intangible assets through acquisition;

$\mathrm{TCl}=$ Total Cash flow for investment purposes in Intangible Assets;

$\mathrm{AI}=$ Addition of IA through payables and settlement of advance payments.

For the controlling variables, negative earnings is assessed based on how many times negative earnings were reported in the financial statements over the five years of the research period. The total, with a minimum of zero (constantly report negative earnings) and a maximum of 5 (constantly report positive earnings) will be the value used to assess the negative earnings presence variable. Similarly, the timeliness variable will have a maximum value of 5 (always punctual in publishing their financial statements) and a minimum value of 0 (always late in publishing their financial statements). This value will then be used to assess the timeliness variable as one of the controlling variable in the model. Meanwhile, the total assets and total assets number are used to measure the firms' size.

The data analysis technique used in this study is the multiple linear regression test to examine the effect of capitalization rate on value relevance, with timeliness, negative earnings and firm size as the controlling variables. The collected data were analyzed with the descriptive statistic analysis, the classical assumption test, and the multiple regression analysis.

\section{RESULTS OF STUDY}

Before the multiple linear regression analysis was conducted, the individual effect of capitalization rate as the independent variable must first be assessed in order to determine the magnitude of its effect and later compare its effect when the controlling variables are included, in order to obtain a better depiction of how these variables collaboratively affect the value relevance of accounting information. To test the individual effect of the independent variable on the dependant variable, the simple linear regression test is performed.

Table 1. The Individual Effect of Capitalization Rate on the Value Relevance of Accounting Information

\begin{tabular}{|c|c|c|c|}
\hline Variable & Regression Coefficient & t value & Sig. \\
\hline Constant & 0.095 & & \\
\hline Capitalization Rate (X1) & 0.108 & 1.237 & 0.226 \\
\hline R-square & $=0.050$ & & \\
\hline
\end{tabular}

Source: Computed Secondary Data (2021)

Afterwards, the controlling variables were examined to show whether these variables consistently affect the dependent variable. This is to determine whether these variables are valid controlling variables for the model.

Table 2. The Individual Effect of the Controlling Variables on the Value Relevance of Accounting Information

\begin{tabular}{lccc}
\hline \multicolumn{1}{c}{ Variable } & Regression Coefficient & t value & Sig. \\
\hline Negative Earnings Presence & 0.034 & 2.461 & 0.020 \\
Timeliness & 0.077 & 2.756 & 0.010 \\
Firm Size & $2.683 \times 10^{-16}$ & 0.798 & 0.431 \\
\hline
\end{tabular}

Source: Computed Secondary Data (2021)

Timeliness and negative earnings presence both have a sig. value of less than 0.05 . This means that timeliness and negative earnings presence respectively have a significant individual effect on the value relevance of accounting information. Thus, timeliness and 
negative earnings presence are included in the research model as the controlling variables. Despite being frequently shown as a variable that significantly affect the value relevance of accounting information, firm size is shown to have a sig. value of 0.431 . This means that firm size does not have a significant effect on the value relevance of accounting information. Since the sampled data does not show that firm size consistently affect the value relevance of accounting information, firm size is not included as a controlling variable in the model.

In the classical assumption test, based on the one-sample Kolmogorov Smirnov test the research model was shown to be normally distributed, based on the collinearity statistics the model has no indications of multicolinearity, based on the Durbin Watson autocorrelation test the model has no indication of autocorrelation, and based on the Glejser / MedenhallSincich (GMS) test the model has fulfilled the homoscedasticity requirement. Thus, the multiple linear regression analysis is applicable and valid method to analyze the hypothesis in this study.

Table 3. Results of the Multiple Regression Analysis

\begin{tabular}{lccc}
\hline \multicolumn{1}{c}{ Variable } & Regression Coefficient & t value & Sig. \\
\hline Constant & -0.170 & & \\
Capitalization Rate (X1) & 0.082 & 0.974 & 0.339 \\
Timeliness (X2) & 0.045 & 1.324 & 0.197 \\
Negative Earnings (X3) & 0.024 & 1.507 & 0.144 \\
\hline Adjusted R-square & $=0.200$ & & \\
F-value & $=3.496$ & & \\
Sig. value of the model & $=0.029$ & & \\
\hline Source: Computed Secondary Data (2021) & &
\end{tabular}

The model has a sig. value of 0.029 and all the coefficients are positive. This shows that that capitalization rate, timeliness, and negative earnings presence simultaneously have a significant positive effect on the value relevance of accounting information. The adjusted Rsquare value is 0.200 which means that 20 percent of the variation in the value relevance variable is explained by capitalization rate, timeliness, and negative earnings presence, while the remaining 80 percent is explained by other variables not included in the model.

Table 4. Multiple Regression Analysis Results with New Sample Criteria

\begin{tabular}{|c|c|c|c|}
\hline Variable & Regression Coefficient & t value & Sig. \\
\hline Constant & -0.121 & & \\
\hline Capitalization Rate (X1) & 0.132 & 1.685 & 0.103 \\
\hline Timeliness (X2) & 0.029 & 0.871 & 0.391 \\
\hline Negative Earnings (X3) & 0.023 & 1.460 & 0.155 \\
\hline Adjusted R-square & $=0.165$ & & \\
\hline F-value & $=3.114$ & & \\
\hline Sig. value of the model & $=0.041$ & & \\
\hline
\end{tabular}

Source: Computed Secondary Data (2021)

On the other hand, the partial effect of capitalization rate on value relevance has a sig. value of 0.339 . This indicates that, despite the inclusion of timeliness and negative earnings presence as the controlling variables, the effect of capitalization rate on the value relevance of accounting information is still not significant. Thus, the research hypothesis $(\mathrm{H} 1)$, which states that the capitalization rate of internally generated intangible assets has a significant positive effect on the value relevance of accounting information, is rejected.

Following this result, the researchers attempted to include more firms into the sample by erasing sample criterion (5) which limits the sample to only firms using Indonesian Rupiah as their reporting currency. However, after the selection process the total sample is 33 firms, or only an addition of 2 firms could be added into the sample because most do not provide enough information to calculate the internally generated intangible assets. It can be inferred 
that a very limited number of firms provide barely enough information to assess the capitalization rate of internally developed intangible assets.

With the new sample, it was also found that negative earnings presence and timeliness were applicable as the controlling variables, while firm size remains not applicable. The data also fulfills the classical assumption test, therefore the multiple linear regression analysis can be used to examine the data. The multiple linear regression analysis results is presented in the table 4.

The partial effect sig. value of capitalization rate on the value relevance of accounting information is 0.103 which is greater than 0.05 . This indicates that, despite the inclusion of timeliness and negative earnings presence as the control variables, the capitalization rate of internally developed intangible assets still does not show a significant effect on the value relevance of accounting information. This proves that hypothesis $\mathrm{H} 1$, which stated that capitalization rate has a significant positive effect on the value relevance of accounting information, is rejected.

On the other hand, the model has an F-value of 3.114 and a sig. value of 0.041 . This shows that capitalization rate, timeliness, and negative earnings presence have a significant simultaneous effect on the value relevance of accounting information. This indicates that in the process of making investment decisions, investors consider the three variables simultaneously or collectively, instead of individually. The results also show that the adjusted R-square value is 0.165 , which means that 16.5 percent of the variation in value relevance is explained by capitalization rate, timeliness, and negative earnings presence, while the remaining 83.5 percent is explained by other variables not included in the model. This percentage value contains significant information considering the many different possible information noises available in the market.

\section{DISCUSSION OF RESULTS}

The research hypothesis $\mathrm{H} 1$ states that Firms with a greater capitalization rate for the internally generated intangible assets have a higher level of value relevance of accounting information than firms with lower capitalization rate. In order to examine this hypothesis, the multiple linear regression analysis was conducted. First, the individual effect of the capitalization rate was examined in order to obtain a clear picture of how the factor individually affect value relevance and afterwards determine whether the controlled variables needs to be included to obtain a more accurate depiction of the relationship.

Based on the results above, the sig. value of the individual effect of capitalization rate on value relevance in the simple linear regression model is less greater than 0.05 . This indicates that without the control of any other variable, the effect of capitalization rate on the value relevance of accounting information is insignificant. This result is expected considering that there are a large number of factors that may potentially affect the value relevance of accounting information.

With the need to include the controlling variables, after testing its individual effect using the simple linear regression analysis, it was found that, respectively, timeliness of publication and negative earnings presence consistently have a significant effect on the value relevance of accounting information. This is consistent with some of the results emphasized in the research published by Erliza et al. (2019), Richard et al. (2019), Badu and Kingsley. (2018), Sixpence et al. (2018), Xu et al. (2016), Dinh et al. (2015), Bokpin (2013), and Nugraheni (2011), in terms of the existing association between negative earnings and value relevance, and between timeliness and value relevance. However, firm size was found to have an insignificant effect on the sampled firms' value relevance of accounting information. Therefore, only timeliness and negative earnings presence are included in the model as the controlling variables.

By conducting the the multiple linear regression analysis with value relevance as the dependent variable and capitalization rate as the independent variable, along with timeliness and negative earnings presence as the controlling variables, the model has a sig. value of less than 0.05 . This shows that capitalization rate as the independent variable, along with 
timeliness and negative earnings presence as the controlling variables, have a significant simultaneous effect on the value relevance of accounting earnings and book value. In addition, the coefficients are all positive, which means that the effect of these variables on the value relevance of accounting information is positive.

However, the partial effect of capitalization rate on value relevance was still found to have a sig. value of greater than 0.05 , even after the addition of non-Indonesian Rupiah reporting firms are added to the sample. This shows that in both sample criteria, the research hypothesis $\mathrm{H} 1$, which stated that firms with a greater capitalization rate for the internally generated intangible assets have a higher level of value relevance of accounting information than firms with lower capitalization rate, is rejected.

Despite the theoretical justification as well as alignment with the accounting principle, the data shows that investors do not consider comparing the rate in which expenditures that potentially have future benefit for the firm are capitalized as significant in the process of making investment decisions. Based on the data, with all listed firms in the IDX as the population, only 31 firms were found to report detailed information regarding their intangible assets. When the firms that do not use Indonesian Rupiah as their reporting currency are included in the sample, there were only 33 firms that provide detailed information regarding their intangible assets. This shows that a very limited number of firms provide barely enough information to assess the capitalization rate of internally developed intangible assets. This finding is in line with study by Owino and Nixon's (2021) which stated that despite being an important component of valuation, intangible investment assets are largely ignored or given subjective treatment, leading to the insufficient reporting of R\&D expenditures which is inadequate for valuation purposes. Due to this limited number of firms providing enough information, the majority of investors do not consider capitalization rate as a significant aspect in their assessment of accounting information usefulness. In making a portfolio, if very few firms provide enough information to calculate capitalization rate, investors may not consider comparing the capitalization rate as a significant aspect to compare.

\section{CONCLUSION}

Based on the research analysis and discussion of results, it can be concluded that the capitalization rate for internally generated intangible assets does not have a significant effect on the value relevance of accounting information, even with timeliness and negative earnings as the controlling variables. This study is unable to provide enough empirical evidence to prove that capitalization rate affects the value relevance of accounting information. One of the research implications is that in Indonesia, a greater capitalization rate does not entail investors to have greater apprecition towards the accounting information provided in financial reports.

The data also shows that even with the addition of firms that do not use Indonesian Rupiahs as the reporting currency into the sample, the number of firms that provide enough information to calculate internally generated intangible assets are still very few. This shows that most firms do not consider providing detailed information regarding their intangible assets to investors as important. Consequently, investors are less able to accurately make comparisons regarding the capitalization of development expenditures in the process of making investment decisions. This may also be one of the reasons why the data analysis results showed that capitalization rate does not have a significantly effect on value relevance, but capitalization rate, timeliness of publication, and negative earnings presence have a significant simultaneous effect on the value relevance of accounting information. The other implication of this study is that there are very few firms that provide enough data to calculate the internally developed intangible assets, which does not allow investors to accurately compare this aspect of the firm. This is in line with Owino and Nixon (2021) who stated that intangible investment assets are largely ignored or given subjective treatment, leading to the insufficient reporting of $R \& D$ expenditures which is inadequate for valuation purposes.

With this being the case, other researchers may consider studying the capitalization rate of firms listed in other stock exchanges that may have higher exposure in terms of their 
intangible assets details. Considering the few numbers of firm providing detailed information regarding their intangible assets, it is advisable for firms to provide greater details in order to allow investors to assess the capitalization rate of firms.

\section{REFERENCES}

1. Asthana, S. and Chen, L.H. (2007). Differential Changes in the Value Relevance of Earnings and Book Value Over Time: Financial Versus Other Industries. Working Paper, College of Business, the University of Texas, San Antonio.

2. Atiase, R. K., Bamber, L. S., \& Tse, S. (1989). Timeliness of financial reporting, the firm size effect, and stock price reactions to annual earnings announcements. Contemporary Accounting Research, 5 (2), pp. 526-552. doi:10.1111/j.1911-3846.1989.tb00722.x

3. Badu, B., and Kingsley, O. A. (2018). Value Relevance of Accounting Information: An Emerging Country Perspective. Journal of Accounting and Organizational Change, 11 (2), pp. $31-52$.

4. Balachandran, S. V., and Mohanram, P. S. (2010). Is the Decline in the Value Relevance of Accounting Driven by Increased Conservatism? Review of Accounting Studies, 16 (2), pp. 272-301.

5. Beisland, L. A. (2008). Essays on the Value Relevance of Accounting Information. Dissertation submitted to the Department of Accounting. Auditing and Law at the Norwegian School of Economics and Business Administration, Bergen, Norway.

6. Beisland, L. A., and Hamberg, M. (2013). Earnings Sustainability, Economic Conditions and the Value Relevance of Accounting Information. Scandavian Journal of Management, 29 (3), pp. $314-324$.

7. Bokpin, G. A. (2013). Determinants and Value Relevance of Corporate Disclosure: Evidence from the Emerging Capital Market of Ghana. Journal of Applied Accounting Research, 14 (2), pp. $127-146$.

8. Chandrapala, P. (2013). The Value Relevance of Earnings and Book Value: The Importance of Ownership Concentration and Firm Size. Journal of Competitiveness, 5 (2), pp. $98-107$.

9. Collins, D.W., Pincus, M., and Hong Xie. (1999). Equity Valuation and Negative Earnings: The Role of Book Value of Equity. The Accounting Review, 74(1), pp. 29-61.

10. Devi, S., Warasniasih., N. M. S., Masdiantini, P. R., and Musmini, L. S. (2020). The Impact of COVID-19 Pandemic on the Financial Performance of Firms on the Indonesia Stock Exchange. Journal of Economics, Business, and Accountancy Ventura, 23(2), pp. $226-242$.

11. Dinh, T., Kang, H., and Wolfgang, S. (2015). Capitalizing Research and Development: Signalling or Earnings Management? European Accounting Review, 25 (2), pp. 373-400.

12. Erliza, S., Erwin, A., and Murni, D. (2019). Analysis of Factors That Affect the Timeliness of Submission of the Financial Statements on Transportation Companies in Indonesia Stock Exchange. International Journal of Research and Review. 6 (1), pp. $190-201$.

13. Flores, E. and Lopes, A. B. (2019). Decrease in the Value Relevance of Accounting Information in Electric Distributors after the Brazilian IFRS adoption. Revista Brasileira De Gestão De Negócios Review of Business Management, 21 (4), pp. 928 - 952.

14. Ghozali, I. (2016). Aplikasi Analisis Multivariate dengan Program SPSS. Semarang: Badan Penerbitan Universitas Diponegoro.

15. Hayn, C. (1995). The information content of losses. Journal of Accounting and Economics, 20, pp. 125-153.

16. Holthausen, R.W. and Watts, R.L. (2001). The Relevance of the Value-Relevance Literature for financial Accounting Standard Setting. Journal of Accounting and Economics, 31, pp. $3-75$.

17. Hui, K. W., Nelson, K. K., and Yeung, P. E. (2016). On the Persistence and Pricing of Industry-Wide and Firm-Specific Earnings, Cash Flows, and Accruals. Journal of Accounting and Economics, 61 (1), pp. $185-202$. 
18. Kamran, A., and Haim, F. (2006). The Value Relevance of Management's Research and Development Reporting Choice: Evidence from Australia. Journal of Accounting and Public Policy, 25, pp. $231-264$.

19. Kousenidis, D. V., Ladas A. C., and Negakis, C. I. (2009). Value Relevance of Conservative and Non-conservative Accounting Information. International Journal of Accounting, 44, pp. $219-238$.

20. Laerd Statistics. (2013). Multiple regression using spss statistics. Lund Research Ltd. (https://statistics.laerd.com/spss-tutorials/multiple-regression-using-spss-statistics.php). Accessed on the 10th of August 2020.

21. McGee R.W., Tarangelo T., Tyler M. (2008). The Timeliness of Financial Reporting: A Comparative Study of Companies in Russia and the European Union. Corporate Governance in Transition Economies. Boston: Springer, Boston, MA, pp. 165 -171.

22. Nugraheni, B. L. Y. (2011). The Effect of Negative Earnings Towards the Value Relevance of Accounting Numbers. Journal of Management and Business, 10 (2), pp. $247-259$.

23. Ostertagová, E., and Ostertag, O. (2013). Methodology and Application of One-way ANOVA. American Journal of Mechanical Engineering, 1 (7), pp. $256-261$.

24. Owino, M, and Nixon, O. (2021). Accounting Treatment of Research and Development Expenditure: A Critical Literature Review. International Journal of Accounting, Finance and Risk Management, 6 (2), pp. 36-45.

25. Richard G. S., Myrtle W. C., and Jack M. C. (2019). Financial Accounting Theory and Analysis: Text and Cases. John Wiley \& Sons.

26. Sixpence, A., and Adeyeye, O. P. (2018). Perception of negative earnings persistence and value relevance: Evidence from Zimbabwe. Cogent Economics \& Finance, 6 (1). https://doi.org/10.1080/23322039.2018.1559711

27. Sjarief, J., Weli, and Widyastuti, E. (2016). The Internal Control Disclosure, the Executive Compensation, and the Timeliness of Financial Reporting. Full Paper Proceeding BESSH-2015, 24 (3), pp. $1-6$.

28. Su, H., and Berenson, M. L. (2017) Comparing Tests of Homoscedasticity in Simple Linear Regression. JSM Mathematics and Statistics, 4 (1), pp. $10-17$.

29. Valens Research. (2016). R\&D Is an Investment, Not an Expense - How capitalizing R\&D impacts understanding corporate profitability. (https://www.valens-research.com/rdinvestment-not-expense-capitalizing-rd-impacts-understanding-corporate-profitability). Accessed on the 8th of October 2020.

30. Vichitsarawong, T., and Pornupatham, S. (2015). Do audit opinions reflect earnings persistence? Managerial Auditing Journal, 30(3), pp. $244-276$.

31. Vuran, B., and Adiloğlu, B. (2013). Is Timeliness of Corporate Financial Reporting Related to Accounting Variables? Evidence from Istanbul Stock Exchange. International Journal of Business and Social Science. 4 (6), pp. $58-70$.

32. Watts, R. L. and Zimmerman, J. L. (1990). Positive Accounting Theory: A Ten Year Perspective. The Accounting Review, 65 (1), pp. 131 - 156.

33. Watts, R.L. (2003). Conservatism in Accounting Part I: Explanations and Implications. Accounting Horizons, 17(3), pp. 207-221.

34. Wendt, M. J. H. (2010). The Effect of Accounting Conservatism on Value Relevance of Financial Statements. Masters Thesis submitted to Erasmus School of Economics, Erasmus University, Rotterdam.

35. Wyatt, A. (2005). Accounting Recognition of Intangible Assets: Theory and Evidence on the Economic Determinants. The Accounting Review, 80 (3), pp. $967-1003$.

36. Xu, L., Cai, F., and Paterson, W. (2016). Value Relevance of Earnings, Book Value, Revenue, and R\&D. Business Review, Cambridge, 24 (1), pp. 91-97. 